\title{
MEZO-SZINT ÉS JÖVŐFORMÁLÁS: STRATÉGIAI MEGFONTOLÁSOK ${ }^{1}$
}

\author{
(Mezzo-level and Future Shaping: Strategic Apects)
}

\section{GÁSPÁR TAMÁS}

Kulcsszavak:

regionalizmus mezo-szint stratégia fejlesztés változás jövö

A globalizáció és annak lényegéhez tartozó ellenárama, a lokalizáció elötérbe helyezte a mezo-szintet, ezzel a regionalizmust. A tanulmány azt vizsgálja, hogy a stratégiai fejlesztésnek mennyire hatékony területe a régió. A fö következtetése az, hogy az egyéntöl a globálisig terjedö társadalmi szervezödési szinteken a mezo-szint környékén a legkedvezöbb a jövõ alakitásának ereje és az ahhoz való alkalmazkodás viszonya, ezért a régió a fejlesztési stratégiáknak kiemelten elönyös területe lehet.

\section{Bevezetés}

A 21. század első évtizedei fontos határkőnek tünnek a fejlesztési stratégiák területén. A globális hatásokat kiváltó termelési és életmód minták egyszerre hoztak létre problémákat és lehetőségeket. Akár a következmények felől, akár a preferenciák felöl közelítjük, a két tendencia közös metszete a jövö felértékelödése. A fejlesztési stratégiák előrejelzési megalapozása különös figyelmet kap.

A jövővel való foglalkozás térbeli struktúrájában kiemelt jelentőséget kapott a mezo-szint, amelynek egyik megjelenési formája a regionalizmus. A regionális szerveződés azonban lényegi hasonlóságokat mutat a civil szerveződésekkel, lakóközösségekkel és a vállalati világ mezo-szintü szerveződésével (Gáspár 2005). A globalizáció sajátossága, hogy a hagyományos társadalmi szerveződési keretek (pl. klasszikus családok, nemzetállamok) egy részét erodálja, ugyanakkor a közöttük húzódó szinteket, elsősorban a regionális szintet megerősíti, mert az nemcsak ellenárama a globalizációnak, hanem hosszú távú létfeltétele is. Az Európai Unióhoz való csatlakozással a regionális fejlesztés, a regionális pályázatok ismerete szinte létfeltétellé vált.

Szakmai tekintetben ez azt is jelenti, hogy a térben szervezett munkamegosztási körök külső kapcsolatait is újra fel kell dolgozni mind elméletben, mind gyakorlatban. A stratégiai fejlesztés és ennek jövőhöz való viszonyában az eddig meghatározó makro-szint kiváló elméleti-módszertani, esettanulmányokkal gazdagított összefoglalását adja Kozma Ferenc munkássága (főleg Kozma 1998 és 2003), melynek folytatása és mezo-szintú adaptációja még elvégzendő feladat.

Több tényezỏ is indokolja tehát, hogy áttekintsük: melyek a mezo-szintü szerveződés sajátos vonásai; illetve felvessük, hogy a jövố formálásának mennyire hatékony szintje a regionális szerveződés, összevetve a jövővel való foglalkozás más térbeli kiterjedésủ szintjeivel. 


\section{A mezo-szint sajátos vonásai}

A jövőhöz való viszony mezo-szintje egyfelől makroszint alatti, másfelöl több mikro-egységet fog egybe: a természetes közösségek nagyobb egységbe szervezésének és jövőalakításának szintjei. Sajátosságuk és nagy elönyük, hogy elég nagy területet vagy elég sok mikro-egységet fognak össze ahhoz, hogy környezetük jövöjének aktív formálói is lehessenek; ugyanakkor elég közel vannak a mikro-szinthez ahhoz, hogy formálandó környezetüket alaposan, közvetlenül ismerjék. Vagyis a jövő alakítása, jövőképek kialakítása nem veszik el a túlzott általánosságban: ember-közeli léptékéből adódóan a mezo-szint jövőhöz való viszonya elég széles horizontú, és föként elég részletes is tud lenni.

Szándékosan mezo-szintről és nem regionális szintről beszélek - vagyis a jelenség belső szerkezete felöl közelítem a problémát, és nem a térstruktúrája irányából. Az aktív jövőformáló eró-potenciál és az eredő hatásokat adó részegységek figyelembe vehetősége együtt a társadalom legkülönbözőbb dimenzióiban tetten érhető. Gazdaságilag ugyanúgy van értelme, mint szociológiailag, kulturálisan vagy politikai értelemben. A mezo-szintú megnevezés általánosabb, mint a regionális, és azt kívánja hangsúlyozni, hogy a szervezőelv nem a térbeliség, hanem a jövőhöz és az egyénekhez való viszony. Persze a társadalom különbözö mezo-szerveződéseinek vannak jellemzö térbeli paraméterei, azonban a fenti megközelítés lehetőséget ad arra is, hogy a regionalizmust és a stratégiai fejlesztés regionális szintjét más módon közelítsük, új módon értelmezzük. Néhány példa az egyes társadalmi dimenziók mezo-szervezödéseire.

A család-közösségek nagyobb egysége volt a kora középkorig a legalapvetőbb mezo-szint. A nemzetségek közössége, mint vér szerinti és tudati összetartozás azonban a fejlettnek mondott világban önállóan ma már nem jellemző. Réteg formájában azonban ma is él, de nem a nemzetség vér-vonala alapján, hanem az egymáshoz tartozás érzése szerint. Patriotizmus most is fellelhetó abban az ösztönös vonzásban, akármilyen minimális is, amely egy társaságon belül ébred, ahol kiderül, hogy a másik is jászsági vagy ormánsági. Számos civil szervezet is alakult erre a „nemzetségcsökevényre": ilyen például a Somogyiak Baráti Köre, amely a Budapestre származott somogyiakat fogja össze, élő módon jeleníti meg programjaiban a somogyság modern megjelenését, ugyanakkor a somogyi jövő formálásának aktív résztvevője is.

A lakóközösségek természetes életterük, közös környezeti hatásaik és hasonló hagyományaik alapján alakítanak mezo-szintü együttmüködést. A közösség érzés itt leginkább csak a háttér: a jövőnek való kiszolgáltatottság elhárítási esélye és a felemelkedés technikai-pénzügyi egymásra utaltsága sodorja inkább egymás látóterébe a térségek lakóközösségeit. Az információs technológia terjedésével ésszerübb és hatékonyabb is a korábbi, kisebb egységü államigazgatási rendszerek (pl. megyék) nagyobb egységekben kezelése (régiók), egyben kisebb egységekben való müködtetése (kistérségek). Ugyanakkor újra egységesen alakithatják a jövőjüket a határok által szétszabdalt természetes egységek. A regionalizmus tehát társadalmi képződményként kezeli a mezo-szintet, és központi fogalma, a régió más-más térszerkezetet vesz fel aszerint, hogy természeti vagy társadalmi-gazdasági jellemzők szerint húzzuk meg határait, avagy a kulturális identitás, etnikai sajátosságok vagy területi igazgatási szempontok rajzolják meg érvényességi körét (Lengyel-Rechnitzer 2004, 28). 
A vállalati szférának is van mezo-szintủ szervezödése, ha nem is stabil és tipikus formaként. A vállalati szövetségek előnye, hogy érdekérvényesítö képességük többszörösen meghaladhatja az egyes kisvállalatok összesített jövőformáló képességét; ugyanakkor szerződéses intézményesítettségük elég rugalmas is ahhoz, hogy a változó feltételekhez szervezetileg is folyamatosan alkalmazkodjanak.

A termelési vagy forgalmazási szövetkezetek ezeknek az együttmüködéseknek stabilabb formái. Lényegében mezo-szint egy-egy oligopólium körül kialakuló holdudvar is: a mag-vállalat és a vele munkamegosztási együttmüködésben élö bedolgozói kör. A stratégiai szövetségek rövidebb-hosszabb ideiglenességgel létrejött mezo-szintủ müködési egységek, amelyek a jövő eredményesebb formálódását kombinálják a változás rugalmasságával.

Széles skálája alakult ki a vállalati szövetségeknek. Az informális, domináns magatartást követő piaci helyzettől a formális kartell megállapodásokon keresztül a technológiai munkamegosztásig vagy közös vállalatig (Child-Faulkner 1998). A kialakuló hálózati gazdaság az információtechnológiai eszközökkel és az egyéni szükségletekre termelés jövőképével a leginkább rugalmasan és hatékonyan képes múködtetni a gazdasági mezo-szintet.

A mezőgazdasági szövetkezetek logikailag a mezo-szinthez tartoznának. Az agrárium modern múködtetésének alapja azonban, az utóbbi évtized szemléletét kivéve, nem a kisparcellás gazdálkodás, illetve ezek valamilyen formájú együttmüködése, hanem eredendően nagyobb területi egységek müvelése. Ezért a szövetkezeti típusú nagyobb egységek inkább a mikro-szinthez sorolódnak.

Bármelyik megjelenési formáról is legyen szó, a mezo-szint különös átmenet a mikro- és makro-szint között: még szinte közvetlenül számba vehető a részt vevő egységek, részrendszerek önálló viszonya a jövőhöz, de összességük viselkedése már mutat mindezektől eltérő, makroszkópikus vonásokat. Illetve, a makro-szint jellemzöinek „szórásértékei” felfedezhetők a mezo-jelenségekben, ezeket az általánosságokat azonban úgy tudjuk árnyalni, fokozatokra bontani, hogy eközben lényegében a mikro-egységekre magukra találunk rá.

A mezo-szint esetében még mindig meghatározó az alkalmazkodás a jövőhöz való viszonyban, ugyanakkor ugrásszerüen megnő az alakítás lehetősége a mikro-szinthez képest. Ez föként abból adódik, hogy a megnövekedett számú rendszer belső kötőereje lehet nagyon erős: a regionális együttmüködés kistelepülései vagy egy stratégiai szövetség vállalatai jól ismerik egymást, kiszámítható a partnerek magatartása és jövőhöz való viszonya. Vagyis a jövővel való foglalkozás a mezo-szinten sokkal inkább a játékelmélet szabályai szerint formálódik, mint egymástól idegen, önálló tevékenységek statisztikai átlagaként. Mindebből következően a változáshoz való viszony is kedvezö lehet: a rendszer belső kohéziójából következöen a reakcióidő leröviditésére és aktív visszahatásra nagyobb az esély - ezért is hozzák létre többek közőtt ezeket a területi vagy munkamegosztási stratégiai szövetségeket. Egy másik dimenzió szemszögéből a jövővel való foglalkozás mezo-szinten elég széles területet fog át ahhoz, hogy stratégiai módon tudjon érvényesülni, és elég mély is tud lenni ahhoz, hogy az operacionalizált, taktikai szinttől ne szakadjon $\mathrm{el}^{2}$. 
A mezo-szervezödés és a változás kapcsolata a jövővel való foglalkozás egyes szintjein

A stratégiai fejlesztés lényegében a változás felismerése, és sodrásának vagy lehetöség szerint az irányának a kézben tartása. A jövő egyik legfontosabb tényezőjének számít, és a jövővel való foglalkozás egyes szintjei szoros kapcsolatot mutatnak vele. A változásról és annak a jövőkutatással való összefüggéseiről részletesen beszámol magyarul Nováky (2005), illetve a nemzetközi irodalomban McHale (2003), Buzan (2005), Holman-Devane (1999).

Jelen vizsgálódásban a témát a szerint közelítjük, hogy a változás mely belső mechanizmusai mutatnak korrelációt az egyes szintekkel. Ehhez a változás két összetevőjét különböztetném meg: a változás egyrészt úgy jelenik meg, mint alkalmazkodás, másrészt, mint a jövő alakitása.

A jövőhöz való alkalmazkodás és a jövő alakítása nem független egymástól. Bonyolultságukat jelzi, hogy két mechanizmus szerint is találhatunk összefüggést közöttük. A változás és a jövővel való foglalkozás egyes szintjeinek relációját az l. ábra mutatja.

\section{1. ÁBRA}

A változás tényezöi és a szintek kettôs mechanizmusa

(The Factors of Change and the twin Mechanism of Different Levels)
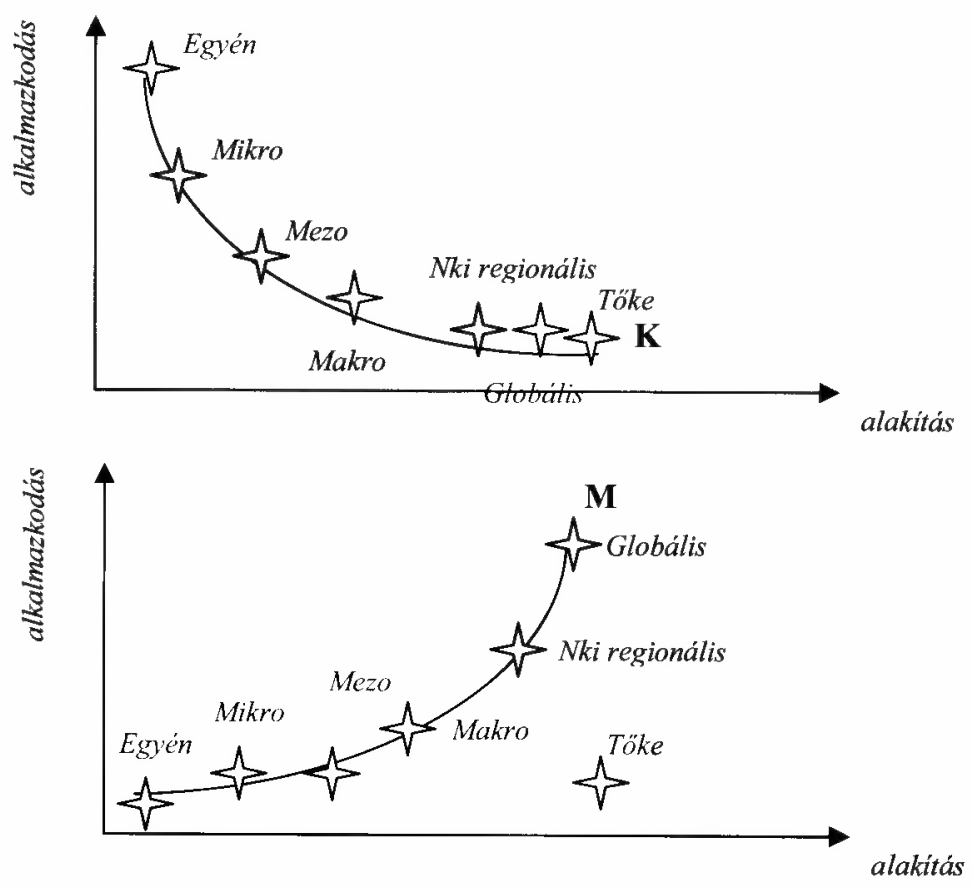

Forrás: Saját szerkesztés. 
A változás két tényezője, a jövőhöz való alkalmazkodás és a jövő alakítása nem kiegyensúlyozottak, és nem egyformán jelennek meg az egyes szinteken. Az egyik összefüggés szerint, amelyet a $\mathrm{K}$ görbe jelöl, a jövő alakítási képessége fordítottan arányos az alkalmazkodási kényszerrel.

A jelenség mögött a társadalom egyes rendszereinek hierarchikus rendje áll. A szerveződések koncentrikusak, részrendszerek alkotják az összetettebb szinteket. Ezek bonyolultsága növekedéséből következik, hogy az alsóbb szinteknek magasabb, önálló struktúrák törvényszerüségeihez kell alkalmazkodni, ez utóbbiak pedig méretben és komplexitásban nagyobb társadalmi kör reprezentánsai. Ennek következtében egyre nagyobb szabadságfokkal képesek a saját és tágabb társadalmi tér jövőformáló erejeként müködni. Az alapmechanizmus szerint mai életünk globális terében a Föld méretü hatásokhoz való alkalmazkodás viszonyában az egyén jövőformáló ereje relatíve kicsi, míg a globális szerveződések alakító ereje a legnagyobb.

Nevezzük ezt a rendszert a szintek hierarchiájának.

Az egymásra épülő szintek integráló jellege nem jelenti a befogadott szintek megszünését, sem pedig azok determinisztikus meghatározottságát. A hierarchikus szerveződés belső jellege széles skálán mozog: a mereven centrálisan szervezödő, felfelé egyoldalúan domináns modellektöl (az ázsiai termelési mód például történelmileg ilyen volt) a szabad civil szervezödések nyitott modelljéig (lényegében elméleti konstrukció) sokféle elképzelhetỏ. Az egészséges zóna valahol ott húzódik, ahol a szerveződésében egyszerúbb szintek jövőhöz való viszonya önálló mozgásterü, saját szintjén maximálisan hatékony, de alrendszerként igazodik a természetitársadalmi törvényeknek az összetettebb szinteken megnyilvánuló dominanciájához. Az Európai Unió szubszidiaritás elve hasonló rendszert céloz meg. De egyszerü példa a mindennapi életből: az ember maga dönti el, hogy elmegy-e horgászni, de azért a kicsi gyerekek fürdetésénél este már számítanak rá; azért a munkáját el kell végeznie, ha meg akar élni; igazodnia kell a tilalmi idöszakokhoz, ha a következö évben is élvezni akarja a horgászást; és nem vásárol olyan felszerelést, etetó anyagot, amely súlyos károsanyag-kibocsátás árán készült - ha azt szeretné, hogy még az unokája is horgásszon.

A szintek hierarchiajja nem merev struktúra: dinamikus és nyitott. Paradox módon, a nagyobb szabadságfokú szintek összetettségéből következik, hogy azok a jövőformáló képességüket az összes integrált alsóbb szint bonyolult összekapcsolódásától kapják: vagyis a jövővel való foglalkozás növekvő szabadságú szintjeivel a rész-szintek iránti növekvö alkalmazkodás is együtt jár. Ezt az összefüggést jelöli az $\mathbf{M}$ görbe.

Maga az egyén sem egyszerủ képlet, hiszen bonyolult fizikai, pszichés és szociális hatások eredójeként gondolkodik és cselekszik jövője érdekében. Vagyis alapvetően saját maga az, akihez alkalmazkodnia kell a maga szintjén - egyébként szuverén döntési helyzetben van. A nemzetközi regionális, globális szintek viszont annyi önálló részrendszert foglalnak magukba, hogy ezek nagy számának mozgásai és kölcsönhatásai szinte kiszámíthatatlanná teszik, ezzel együtt nagymértékben belső bizonytalansággal ruházzák fel az összetettebb rendszerek potenciálisan nagy jövő- 
alakítási képességét. Ez az egyik fó problémája a globális modellek Tỉnbergenjelentésében megfogalmazott világkormány elképzeléseknek.

2. ÁBRA

A jövö alakitási lehetösége a komplexitás függvényében

(Future Shaping in the Function of Complexity)

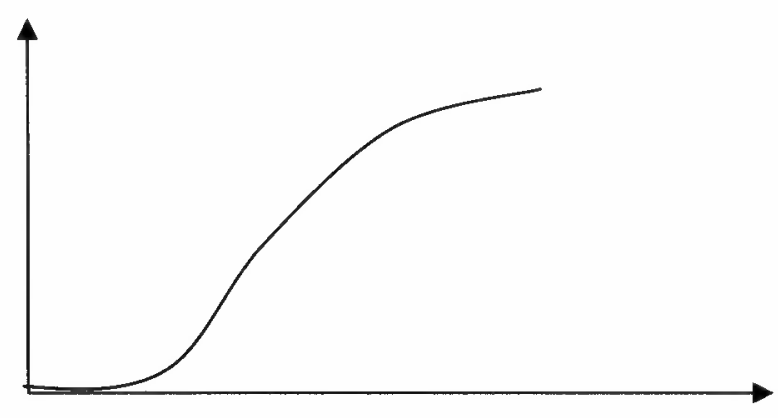

komplexitás

Forrás: Saját szerkesztés.

A két mechanizmus között a rendszerek komplexitása hoz létre kapcsolatot (2. ábra). Az egyes szintek bonyolultságával ugyanis nem egyenes arányban változik a jövő alakítási képessége - leginkább logisztikus összefüggést mutat. Eleinte az összetettség növekedésével ugrásszerúen nő a jövőformáló erő: a szinergikus hatások nagymértékben megnövelik az adott szinten együttmúködők hatékonyságát. Valahol a mezo-makro-szint nagyságrendjénél azonban a komplexitásból adódóan az egyes ember számára a rendszer átlátása és kontrolálása-irányítása egyre nagyobb nehézségekbe ütközik. A jövő alakitási képessége továbbra is nő, hiszen a komplexitás növekedésével egyre több jelenség a rendszeren belül alakul ki, vagyis egyre több jövöcsíra születik az adott szinten belül. A jövő azonban a születó alternatívák egyre nagyobb számának következtében egyre bizonytalanabbá, a jövő́csírák felismerése és kezelése pedig egyre nehezebbé válik, ezért a növekmény csökkenö mértékủ.

A 3. ábra a komplexitásból adódó rendszerösszefüggések következményeit mutatja. A rendszer két mechanizmusa együttesen érdekes képet produkál: a komplexitás jövőformáló potenciáljának exponenciális szakaszában a szintek bonyolultságának növekedése eleinte a $\mathrm{K}$ görbe szerinti összefüggést teszi dominánssá, ezért a jövő alakítási lehetősége mellett relative csökken az alkalmazkodási kényszer. A komplexitás belsö korlátjának jelentkezésével (inflexiós pont) azonban a változás vezérlési képessége mellett erőteljesebben érvényesül a saját és a belső rész-szintek iránti alkalmazkodás szükségessége, vagyis az $\mathrm{M}$ mechanizmus válik meghatározóvá. A végeredmény a társadalmi szerveződés szintjeinek u-alakú görbéje, amelynek minimuma a külső-belső alkalmazkodáshoz képest maximális jövőalakítási képességet jelöli. Az egyén társadalmi méretü jövőalakitó ereje általában önmagában kicsi. Azt 
gondolnánk viszont, hogy az intézményi szervezödések tágulásával ez az erő fokozatosan nőni fog. A globális szint felé azonban a jövőformálási potenciált egyre nagyobb mértékben rontja a rendszer komplexitásából adódó alkalmazkodási kényszer. Továbbá, a globális rendszerek alapegységei is egyének, amelyek tömeges, szervezett és technológiailag kitágított organizációs készsége sem képes a biológiai, pszichés és szellemi korlátait túllépni. Ezért a nagyfokú alakítási lehetőség és alkalmazkodási kényszer eredője a globális szint környezetében a stratégiai látásmódot, dőntéshozatali mechanizmusokat és cselekvési eredményességet tekintve kevéssé hatékony. A minimum pont, a stratégiai tervezés kialakítása és végrehajtása vonatkozásában relatíve legeredményesebb szerveződési szint valahol a mezo-makro szint környékén van.

\section{3. ÁBRA}

Az egyes szintek változáshoz való viszonyának rendszerösszefüggése

(The Relation of Differenct Social Levels to Change - a Complex View)

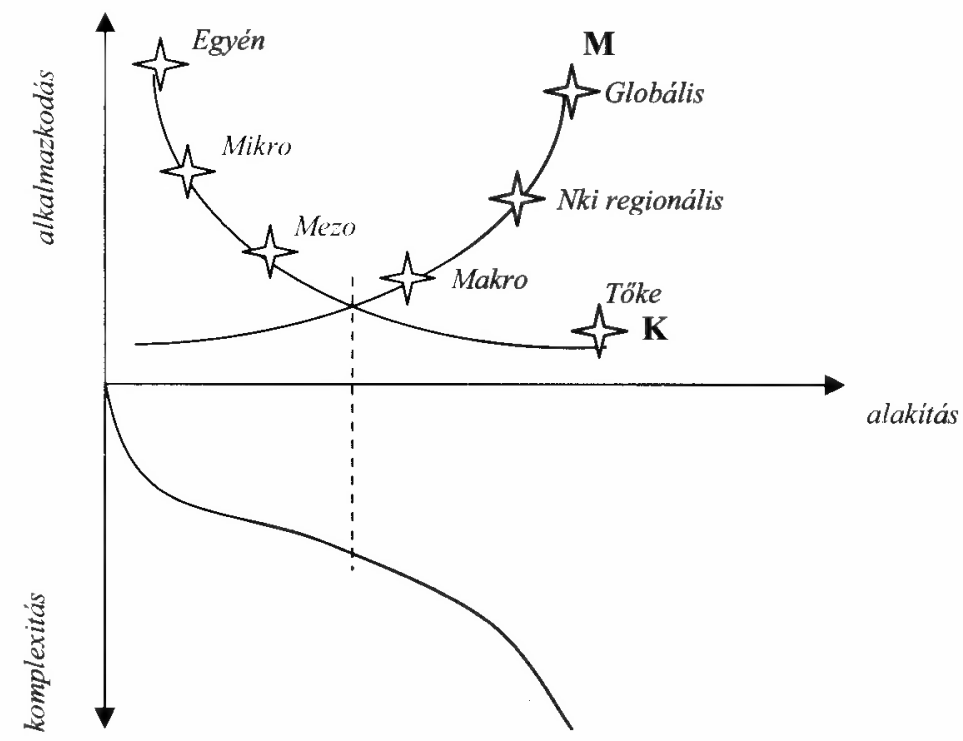

Forrás: Saját szerkesztés.

A globalizált világ azonban ennél bonyolultabb, és van a fenti minimumpontnál is kedvezőbb helyzetü szint. A világ gazdasági és technológiai egységesedésének utóbbi évtizedeit ugyanis a termelési tényezők közül kizárólag a tỏke globalizáltsága vezényelte le. Vagyis a világméretủ intézmények körében a tőkére nem igaz a fenti megállapítás: óriási ereje meghatározó jövőformáló energia, ami saját eredményességén kívül nemigen van alkalmazkodási kényszerben, semmilyen tekintetben. A világ gazdaságát az utóbbi időben átformáló latin-amerikai, kelet-ázsiai stb. válságok magukért beszélnek, a tőke globális mozgásának következményei. Ezért a tökét 
külön vettük a globális szinttől, tulajdonságai elvileg a legkedvezőbb helyzetbe hozzák. A probléma föként abból adódik, hogy a tóke mozgástörvényei önmagukban nem kompatibilisek a stratégiai időhorizonttal, és jövőformáló potenciáljuk elsősorban a rövid táv optimalizálását célozza meg.

A stratégiai tervezés mai világának egyik alapvető konfliktusát mutatja ebböl a szempontból a 3. ábra: amíg az emberléptékủ mezo-szerveződés a stratégiai tervezés hatékony szintje volna a térben és időben, addig a globális méretủ tőke cunamierejü sodrásai a felismerhetetlenségig torzithatják, vagy elsöpörhetik ezeket az erőfeszítéseket. Íme a globalizáció kettőségének, a globális és regionális jelenségek egymást létrehozó és egymásnak ellentmondó hatásainak újabb példája.

Mindazonáltal az ábra azt mutatja, hogy a globalizációval egyre meghatározóbbá váló regionális jelenségeknek racionalitása valahol a fenti mechanizmusokban húzódik, és alátámasztja azt a nem magától értetődő törekvést, hogy a fejlesztési stratégiákat erőteljesebben érdemes regionális szintre hozni. Az alapösszefüggést azonban mind a tér, mind az idő jellege nagymértékben befolyásolja.

\section{A mezo-szervezödés a szintek téridö dinamikájában}

Bizonytalan időszakokban ủjrarendezödik a hierarchia, és ilyenkor az egyéni vagy mikro-szinteknek is lehet meghatározó jelentősége. Ezt mutatja a 4. ábra.

$$
\begin{gathered}
\text { 4. ÁBRA } \\
\text { A szintek változáshoz való viszonya instabil és sürübben szervezett téridö } \\
\text { körülmények között }
\end{gathered}
$$

(The Relation of Social Levels to Change Under Unstable Circumstances and Closely Organised Space and Time)

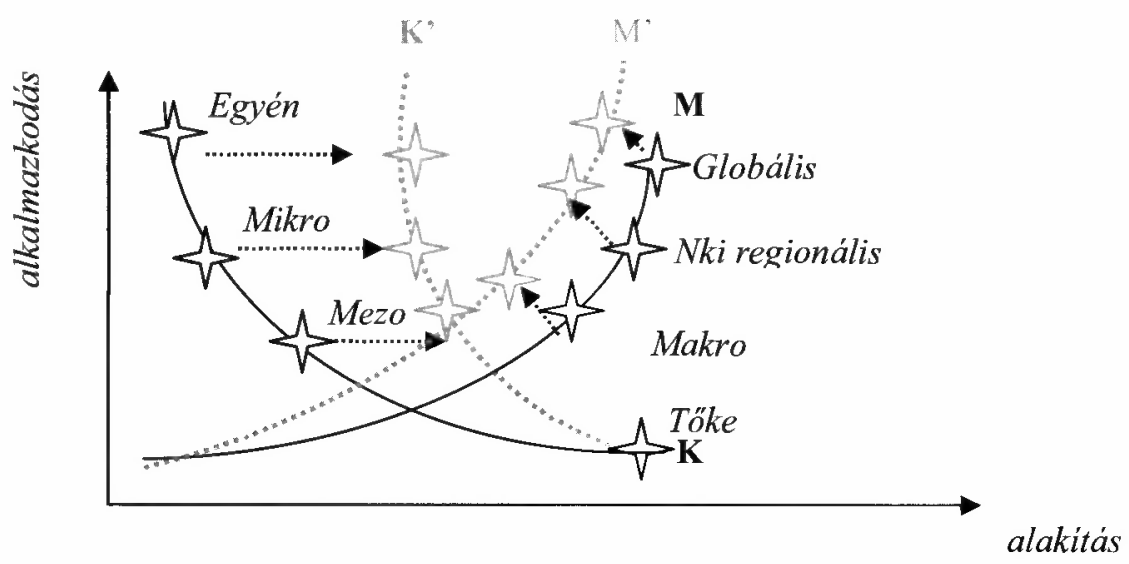

Forrás: Saját szerkesztés. 
Az individuális egyén „nem tehetek semmit” érzése, a kis változások statisztikus kiegyenlítődése a stabil időszakok törvényszerüsége. Korszakváltás idején az egyéni, illetve egyszerübb szintü várakozásoknak és tetteknek sokkal nagyon szerepe van: amikor a bevett társadalmi szokások és várakozások már nem nyújtanak biztos fogódzót az egyéneknek, akkor az új magatartási minták versenye, gyors mozgása és a társadalom nyitottsága ezekre a „kísérletekre” felerősítheti akár az egyén szintjén vagy a kis mértékú változásokban megjelenö újdonságokat is. A változás összetevőinek $\mathrm{K}$ mechanizmusa megváltozik: az alakító erö hirtelen felértékelődik az alkalmazkodáshoz képest, vagyis a $\mathrm{K}$ görbe jobbra eltolódik ( $\left.\mathrm{K}^{\prime}\right)$. Az eltolódás azonban nem egységes: az egyszerübb rendszerek relative nagyobb mozgásteret kapnak, ahogy közeledünk az összetettebb szintek felé ez a felértékelödés a komplexitás tehetetlenségi mozgásánál fogva csökkenő mértékủ. Vagyis eltolódása közben a görbe elfordul. Hasonlóképpen, az M összefüggéssel jelzett mechanizmus is megváltozik. Az egyszerủbb részrendszerek felértékelödésével, vagyis azzal, hogy mozgásuk önmagában az eredő hatást a korábbinál nagyobb mértékben befolyásolja, nagyobb belsö alkalmazkodásra kényszeríti az összetettebb rendszer-szinteket: az M görbe felfelé tolódik el (M'). Ez az eltolódás sem egységes, mert a bonyolultabb szintek több részrendszere kiszámíthatatlanabb eredöt produkál, vagyis összességében nagyobb alkalmazkodást követel meg. A felfelé tolódó görbe itt is elfordul.

Végeredményben az egyes szintek stratégiai szempontból közelebb kerülnek egymáshoz, a jövőformálási potenciál diapazonja csökken, továbbá az erősorrend is módosul: az egyéni vagy mikro-szint akár ideiglenesen a makro vagy regionális szint „elé" kerülhet. A nyolcvanas években például nemzetközi méretü stratégiát lehetett építeni a globális méretủ tehetetlenség ellenében, amit az atombomba kölcsönös fenyegetése merevített meg. A „kis lépések politikája” módszeresen aknázta alá a kétpólusú rendszert, és végül annak felbomlását eredményezte (Gáspár 2001).

Másként: a jövőhöz való viszony uralkodó törvényeit fentröl lefelé határozzák meg az egyes szintek, ám amikor ezek a szabályok megkérdőjeleződnek, és az emberek a várakozásaikat nem képesek, vagy nem akarják a megszokott összefüggések szerint alakítani, akkor az egyéni és mikro-szinten megfogalmazott, versengő nézetek újrarendezik a szintek hierarchiáját. A stabil időszakokban is kialakulhatnak instabil helyzetek: a tömegpszichózis jellegzetesen ilyen jelenség. A Valahol Európában címü filmben mindegyik csavargó gyerek tudja a „makro törvényt”, hogy nem szabad ölni, mégis egyikük felkiáltása - „könyörgöm, akasszuk fel!” - majdnem a jótevőjük tragédiáját okozza.

Összességében, ahogy az időtényező megváltozásával közelebb kerültek egymáshoz az egyes szintek a jövőalakítás/jövőformálás viszony tekintetében, a legnagyobb elmozdulást a mikro-kőzeli szerveződések mutatják. Az „elékerülés” azonban korántsem jelenti a hierarchia felborulását. A minimum pont közelében továbbra is a mezo-makro-szint helyezkedik el, de a nagyobb fajlagos jövőformáló javulást a mezo-szint mutatja. A saját lehetőségeinek felértékelődésén túl ugyanis „ki- 
sugárzik"az egyének és mikroközösségeik megnövekedett helyzeti előnye, ami hatványozottan emeli a mezo-szint jövőformáló, stratégiai hatékonyságát.

Helyesebbnek tünik, ha újrarendezésről beszélünk, mint a hierarchia megfordulásáról. A mikro-szintü kezdeményezések ugyanis csak úgy válnak jövőformálóvá, ha megfelelő nagyságú erö van mögöttük. Így a jövő alakításának kezdeményezésére, alternatívák megfogalmazására nagyon alkalmas ez a szint. Rendszer meghatározó szintté azonban csak úgy válik, ha a domináns nézet mögötti hatalmi intézményrendszer egy része felkarolja azt.

A szintek hierarchiája térben sem merev. Ahogy a visszacsatolások időbeli „sürüsödése" módosítja - egyben életszerủbbé teszi - a fejlesztés-stratégiai lehetőségek társadalmi szintek szerinti mechanizmusait, úgy a térbeli sürüsödés is hasonló következményekkel jár. Minél több csomóponton keresztül, minél több szállal összefogott részegységek rendszeréről van szó, annál erőteljesebb az egyszerübb szintek mozgásainak „begerjedési”, tovagyürüzési lehetősége. Barabási kutatásai a hálózati rendszerekről nem véletlenül váltak oly népszerüvé: éppen azt mutatják meg, hogy a skálafüggetlen hálózatok törvényszerüségei miként módosítják a globális rendszerek mozgását (Barabási 2003). A globalizáció magával hozta a tér újjászervezésének technológiai feltételeit is. Az információs technológiák és az ürtechnika kiterjesztik az ember biológiai szervezési és kontrollálási korlátait - igaz, csak meghatározott keretek között. Az utóbbi évtizedek káosz- és hálózatelmélete éppen a „sürübbé" vált téridő törvényszerüségeit írja le, amelynek stratégiai megfontolásai is vannak ${ }^{3}$.

A térbeli nyitottság más vonatkozásban is figyelemre méltó. Kulturálisan jelentős különbségek vannak a tekintetben, hogy az egyes szintek mekkora jelentőséget kapnak, és hogy viszonyulnak a többi szinthez. Például az euro-atlanti kultúrkör egyik fö forrása a germán-római feudalizmus, ahol a kelet-római császársággal ellentétben az egyéni szint a meghatározó. A világtörténelem új és legújabb kora, beleértve az uralkodó közgazdasági és társadalomtudományi nézeteket, ebből a modellből fejlődnek ki, és a globalizáció első szakaszában szélsőséges individualizmusba süllyednek a neoliberalizmussal. Ugyanakkor a klasszikus liberalizmus hazájában, NagyBritanniában és az Egyesült Államokban az individuum tradicionálisan a mikroegyént jelenti: a család, hitközség vagy más erkölcsi közösség által ellenőrzött egyént. A franciáknál, helyi sajátosságaik körében pedig az egyéneket koordináló makroszint kapott történelmileg kiemelkedő helyet. Az ázsiai termelési módot kialakító, illetve az arra épülő keleti társadalomszervezésben viszont a különböző makroszintek meghatározó szerepe jelentette a fenntartható jövőt. Japánban nagyon erős ez az alárendeltség, viszont az egyén nem alkatrésze a közösségének, hanem önálló, kreatív formálója ezért inkább a makro-egyén a japán jellegzetesség. Indiában ugyancsak a makroszint és az egyéni szint a kiemelkedő, viszont ezek elszakadnak egymástól. A kasztrendszer igen merev köteléket jelent, viszont hitük szerint ennek átlépése kizárólag karmikusan, az egyéni tökéletesedés útján érhető el - és folytathatnánk a sort. 


\section{Következtetések}

A mezo-szintủ szerveződés a jövővel való foglalkozás térbeli struktúrájának sajátos helye. Jellemző vonásait elsődlegesen nem a térbeli kiterjedésétöl, hanem szervezödésének minőségi sajátosságaitól nyeri. A társadalmi együttélésünk gazdasági, politikai, szociológiai stb. dimenzióiban más-más kiterjedést jelent. A regionális fejlesztési stratégia tehát a tér szervezésében koncentrikus körök egymáshoz való bonyolult viszonyában kell, hogy gondolkodjon.

A jövővel való foglalkozás az elkövetkező időszak elkerülhetetlen tevékenysége. A regionális fejlesztési stratégia jövökutatási-elörejelzési megalapozása minden eddiginél nagyon szerepet kap - anélkül, hogy az a fejlesztés céltételező és végrehajtó szerepét átvenné.

A jövőhöz való alkalmazkodás és annak aktív formálása egyfajta értelmezése a változásnak. Ebben a rendszerben az alkalmazkodás-formálás-komplexitás többcsatornás összefüggése alapján a mezo-szint kiemelt szerepet kaphat, mert elég eröt és elégséges belső kohéziót tud létrehozni a jövő formálásához. A fejlesztési stratégiák hatékony és kiemelt területe lehet tehát a regionális szint.

Dinamikájában vizsgálva a stabil és instabil időszakok, valamint a ritkább és sủrübb terek között, a jövőhhöz való viszony szintjei tekintetében, a fejlesztési prioritások átalakulhatnak. A mikro és az egyéni szintek jobban felértékelödnek, amelyek felerósítik a mezo-szint létjogosultságát: fokozott hatékonysággal rendelkezik a jövő formálásához, vagyis integráló és katalizáló területe lehet a felértékelödött egyéni-mikro kezdeményezéseknek.

\section{Jegyzetek}

${ }^{1}$ A cikk a BCE Jövökutatás tanszék Jövöelméletek sorozatában megjelenésre tervezett kézirat egy részének, valamint a VI. Jövőkutatási Konferencián benyújtott és elhangzott előadásnak átdolgozott és továbbfejlesztett változata. Köszönöm kollégáimnak és a szekció résztvevöinek az értékes megjegyzéseiket.

${ }^{2}$ A stratégiát és taktikát itt abban az értelemben használjuk, ahogy Kozma Ferenc definiálta a Külgazdasági stratégia címủ könyvében (Kozma 2001, 221-231; 245). A vállalati szintü stratégiai menedzsment másként használja a fogalmakat.

3 A káoszelmélet jövőkutatás-módszertani feldolgozását Novảky Erzsébet és Hideg Éva végezte el (Nováky 1995), a világgazdasági és a globális téridő vonatkozásaihoz pedig lásd Gáspár 2001, 2005.

\section{Irodalom}

Barabási A.L. (2003) Behálózva. A hálózatok új tudománya. Magyar Könyvklub, Budapest.

Buzan, T. (2005) Embracing Change: Essential Steps to Make Your Future Today (Personal Development). BBC Books.

Child, J.-Faulkner, D. (eds.) (1998) Strategies of Corporation. Managing Alliencies, Networks and Joint Ventures. Oxford University Press, Oxford.

Gáspár T. (2001) Korszakváltás a világgazdaságban. - Gáspár T. (szerk.) A természetnek, a müvészetnek, a tudománynak nevében. BKÁE Jövőkutatási Kutatóközpont, Budapest.

Gáspár T. (2005) Idő-tér-korszakváltás. - Kiss E.-Hideg E.--Nováky E.-Gáspár T. (szerk.) Társadalmi tér, idö, téridö a jövơkutatásban. BCE Jövökutatás Tanszék, Budapest. 
Holman, P.-Devane, T. (1999) Change Handbook: Group Methods for Shaping the Future. BerrettKoehler, U.S.

Kozma F. (2001) Külgazdasági stratégia. Aula, Budapest.

Kozma F. (1998) A félperiféria. Külgazdaság-stratégiai kiindulópont Magyarország számára az ezredvégen. Aula, Budapest.

Kozma F. (2003) Magyarország világpiaci illeszkedésének stratégiája. Aula, Budapest.

Lengyel I.-Rechnitzer J. (2004) Regionális gazdaságtan. Dialóg Campus, Budapest-Pécs.

McHale, J. (2003) Communicating for Change: Strategies of Social and Political Advocates. Rowman \& Littlefield Publishers.

Nováky E. (szerk.) (1995) Káosz és jövökutatás. BKE Jövőkutatás Tanszék, Budapest.

Nováky E. (2005) Jövőkutatás a változások hálójában. Kézirat.

\section{MEZZO-LEVEL AND FUTURE SHAPING: STRATEGIC APECTS}

\section{TAMÁS GÁSPÁR}

Globalisation and its counter-flow, that is localisation, have put mezzo-level and hence regionalism to the forefront. The article examines how effective regionalism is regarding strategic development. Its main consequence is that on a social range from the individual to the global the mezzo-level seems to be the most effective in terms of the relationship between the future shaping power as well as the adaptation to future challenges. Region hence may be a highly advantageous field of strategic development. 